\title{
Obserwacja i refleksja - dwie relacje „turystów” z Hiszpanii w XVIII wieku
}

\begin{abstract}
Słowa kluczowe: Giuseppe Antonio Baretti, Edward Clarke, Hiszpania, relacje z podróży, Oświecenie
\end{abstract}

Key words: Giuseppe Antonio Baretti, Edward Clarke, Spain, travel accounts, Enlightenment

W XVIII wieku Hiszpania jako cel podróży była rzadko wybierana. Przedmiotem niniejszego artykułu jest analiza dwóch powstałych w podobnym czasie relacji z wojaży na Półwysep Iberyjski w latach sześćdziesiątych tegoż stulecia. Ich autorami byli: Włoch - Giuseppe Antonio Baretti, który podróżował z Lizbony do Włoch, oraz Anglik — Edward Clarke, który przemierzał Hiszpanię w przeciwnym kierunku. Cechowało ich inne nastawienie i sposób rejestrowania wspomnień, różnie postrzegali obserwowaną rzeczywistość, zauważali i komentowali sytuacje społeczne, wydarzenia polityczne i osobiste spotkania, które miały miejsce podczas podróży. To wszystko znalazło wyraz w ich odmiennych przekazach.

„Warto zabrać sznurek: na wyboistych drogach kufry mogą się łatwo pootwierać. Podróż w lecie, kiedy pogoda będzie uciążliwa wymaga zabrania koszyka, do którego trzeba powkładać winogrona i inne owoce - pomogą ugasić pragnienie. Bukłaki na wino można schładzać w przydrożnych — zimnych — potokach. Dobrze jest mieć pistolety i trzymać je na widoku, w celu odstraszenia ewentualnych napastników. Jeśli ma się służącego [autor tych uwag posiadał takowego - P.D.] niech nosi przy sobie broń: «ogromny muszkiet» i tasak u boku: robią wrażenie na potencjalnych złoczyńcach. Opowieści o rabusiach są najczęściej wyolbrzymione, wieśniacy są grzeczni i nieagresywni. Pojawia się — co prawda — wielu żebraków, a niektórzy — w Estremadura — dopominają się, aby «ucałować ich brudne krucyfiksy i madonny», ale można ich utrzymać w ryzach dobrym słowem (choć widok broni nie zawadzi)"1. Podobnych zaleceń jest więcej i do niektórych, oraz do zawierającej je relacji, wrócimy poniżej. Nie lekceważąc ich wartości należy pamiętać, że należały do zakorzenionego jeszcze w starożytności topicznego aparatu piśmiennictwa peregrynacyjnego, który obce kraje ukazywał jako miejsca niebezpieczne, a ich mieszkańców oraz szerzej — cudzoziemców traktował podejrzliwie.

Znakomite studia Antoniego Mączaka o wieku XVII oraz Johna Ingamells i Jeremy Blacka o następnym wskazały, jak bardzo w życiu Europejczyków zadomowiła się moda na podróżowanie zarówno w celach edukacyjnych — do szkół po nauki, jak i szerzej — poznawczych i rozrywkowych. Odwiedzanie miejsc uznanych za potrzebne dla zdobycia lub uzupełnienia wiedzy, nabycia ogólnej ogłady i towarzyskiego poloru stawało się trwałym elementem edukacji i obyczaju². Ciekawość świata, pozbawiona już lęku przed odległym i nieznanym, kształto-

1 Journey. 1770, t. II, s. 268. Wszystkie tłumaczenia pochodzą od autora.

2 Mączak A. 1984; 1998; Schudt L. 1959; Stewart W.E. 1978; Batten C. Jr. 1978; The Fatal Gift of Beauty. 1996; Chaney E. 1998; Black J. 1985; 1992; Grand Tour. 1996; Adams P. 1978, s. 488-515; A Dictionary. 1997. 
wała horyzonty i wyobraźnię. Rejestr książek wypożyczonych z publicznej biblioteki miasta Bristol, jednego z handlowych centrów Wielkiej Brytanii, wskazuje, że w latach 1773-1784 najwięcej osób (łącznie 6121) pożyczyło lektury (283 tytuły) będące relacjami podróżniczymi. Znacznie mniejszym powodzeniem (3313 pożyczających) cieszyła się literatura piękna ${ }^{3}$. Z podróży przywożono szczególne, osobiste wspomnienia, doświadczenia „inności” oraz pamiątki, czyli znaki pamięci miejsc, wydarzeń i ludzi. W XVIII stuleciu można już mówić o zjawisku turystyki, o całych środowiskach ludzi podróżujących, których motywy, refleksje, zachowania i spostrzeżenia stały się jednym z ulubionych przedmiotów analizy historyków kultury. Zjawisko antycypuje jednak same pojęcia; słowa „turyzm” i „turystyka” pojawiają się w językach europejskich o sto i więcej lat później niż społeczny kontekst podróżowania w celach edukacyjnych bądź rozrywkowych (leisure migration). Analizując ten związek, Jozef Böröcz wskazywał na podstawie dziewiętnastowiecznych przewodników (już w pełni ,turystycznych”) na powstawanie swoistych „map mentalnych” Europy, stereotypowych standardów dotyczących miejsc i krajów, które „trzeba odwiedzić” ${ }^{4}$. Pierwowzory tego procesu sięgały XVII wieku, sto lat potem były już dobrze zakorzenione i zróżnicowane, także pod kątem społecznego pochodzenia podróżnych. Wiadomo, że oświeceniowa turystyka nie dotyczyła tylko dobrze urodzonych. Pośród europejskich wypraw (głównie brytyjskich) z okresu 1547-1830 tylko 17\% podejmowali arystokraci, pozostali podróżnicy rekrutowali się z drobnej szlachty, duchowieństwa, przedstawicieli wolnych zawodów i kupców ${ }^{5}$.

Dalsze uwagi zostaną poświęcone przede wszystkim spostrzeżeniom, które włoski podróżnik Giuseppe Baretti spisał w czasie podróży przez Portugalię i Hiszpanię w 1760 r. ${ }^{6}$ Jego relacja wydana w Londynie w czterech tomach jest o tyle interesująca, że oba kraje nie stanowiły aż po wiek XX atrakcji „turystycznej”, i nie mogły się równać pod tym względem ani z Francją, ani tym bardziej z Włochami. Jak deklarował Samuel Johnson, wyrocznia angielskiego dobrego gustu i smaku — nad Morzem Śródziemnym narodziła się współczesna kultura, a brak wiedzy o niej utrwalał poczucie niższości. Miał jednak na myśli Italię, nie zaś Hiszpanię? Anonimowy brytyjski podróżnik pisał w 1783 r., że „tylko konieczność może zachęcić do podróży do Hiszpanii, tylko idiota zwiedza ten kraj z ciekawości, chyba że chce wydać wspomnienia na temat aberracji natury ludzkiej"s.

W XVIII stuleciu państwa iberyjskie nie przyciągały zbytnio uwagi podróżników. Do Paryża udawali się, aby zakosztować klimatu europejskiej stolicy oświeceniowej kultury, do Italii zaś garnęli się zwabieni nowo odkrytymi (w połowie stulecia) starożytnymi wykopaliskami, widokami Wezuwiusza, magią papieskiej stolicy, architekturą i malarstwem Florencji i wreszcie niezwykłymi doznaniami okresu weneckiego karnawału. Literatura iberyjska, przede wszystkim doby „złotego wieku”, służyła np. we Włoszech za inspirację, ale poza może Cervantesem w XVIII wieku nie zwracała uwagi innych europejskich krytyków, pisarzy i komentatorów9

Mniejsze z państw iberyjskich — Portugalia nie była krajem szczególnie chętnie odwiedzanym. Jej położenie sytuowało ją na skraju kontynentu. Anonimowy brytyjski podróżnik

3 Hunt M. 1993, s. 336.

4 Böröcz J. 1992, s. 708-741.

5 Böröcz J. 1992, s. 710; por. Welch B.A. 1980, s. 10-25.

6 Journey. 1770.

${ }^{7}$ W oryginale: A man who has not been in Italy, is always conscious of an inferiority [...] The grand object of travelling is to see the shores of the Mediterranean. On those shores were four great Empires of the world: the Assyrian, the Persian, the Grecian, and the Roman - All our religion, almost all our law, almost all our arts, almost all that sets us above savages, has come to us from the shores of Mediterranean, Boswell J. 1934-1950, t. III, s. 36.

${ }^{8}$ Cyt. za: Hontanilla A. 2008, s. 123.

9 Staves S. 1972, s. 193-215; Battestin M.C. 1997, s. 295-321; Briesemeister D. 1984, s. 285-310. 
(pseudonim Viator), którego relacje z iberyjskich wojaży wydał (w odcinkach) w 1749 r. miesięcznik „Universal Magazine”, podkreślał architekturę Lizbony, koncentrował się na opisach kościołów i ich bogactwie, a o Portugalczykach miał do powiedzenia tyle, iż są szczególnie zazdrośni o kobiety, a także podatni — ze względu na gorący klimat — na powaby prostytutek. Relację o bójce na noże między angielskimi i portugalskimi marynarzami skwitowano w londyńskiej prasie uwagą, że „na ulicach Lizbony z byle powodu kłótni dźga się nożami”" świadomości Europejczyków Portugalia wdarła się w sposób wyjątkowo dosadny z powodu kataklizmu — zniszczeń, jakie wywołało poranne trzęsienie ziemi w dniu Wszystkich Świętych roku 1755. Wydarzenie to wywarło ogromny wpływ na wyobraźnię współczesnych, zarażając ją — jak u Woltera — znaczną dozą pesymizmu i wątpliwości w sens bożego ładu i porządku świata. Włoski podróżnik, którego relacją będę się zajmować, oglądał zniszczenia i oceniał, że dotyczą obszaru dwa razy większego niż jego rodzinny Turyn. Jego obserwacje były nasycone emocjami. „Ależ to spektakl, kiedy trzysta tysięcy ludzi ogląda, jak ich domy płoną w tej samej chwili” - notował, aby potem zająć się dywagacjami o liczbach i stwierdzić, że „w Lizbonie było dwadzieścia cztery tysiące domów, a dwie trzecie legło w gruzach". Nie próbował ocenić, ilu jego rodaków zginęło, nie wspominał też o stratach wśród kolonii zasiedziałych w Lizbonie angielskich kupców ${ }^{11}$. Na temat liczby ofiar wypowiadał się ostrożnie: „,wydaje się, że w powszechnej opinii Portugalczyków w ruinach miasta zginęło ponad dziewięćdziesiąt tysięcy [ludzi - P.D.]. Przypuszczam, że przesadzają o dwie trzecie [...] ale i tak, krew mi się ścina na samą myśl" "12. Czytał zapewne Listy z Lizbony Henry Fieldinga, autobiograficzny zapis umierającego pisarza, jednej z gwiazd angielskiej literatury i życia publicznego, który zmarł w Lizbonie ponad rok przed trzęsieniem ziemi. Nic jednak nie wskazuje, że udał się na jego grób na cmentarzu parafii św. Jerzego ${ }^{13}$.

Hiszpański ,złoty wiek” aż po koniec XVII stulecia ciekawił przede wszystkim Francuzów, a powodzenie relacji spisanej przez hrabinę d'Aulnay, wydanej w 1691 r. (thumaczonej na angielski w 1740 r.) potwierdzało trwające zainteresowanie przedtem habsburską, zaś w XVIII w. już burbońską monarchią ${ }^{14}$. Anglicy nie tylko podkreślali „tradycję wrogości” wobec Hiszpanii, sięgającą XVI stulecia, ale również ukazywali na hiszpańskim przykładzie swoją religijną

10 „Gentleman’s Magazine”, 1760, vol. 30, s. 199; por. „Universal Magazine”, 1749, vol. 5, s. 1-8, 68-76, 118-125, 174-179, 201-203. „London Magazine”, 1760, vol. 29, s. 652, relacjonował we wrześniu 1760 r., że: „o dziewiątej wieczorem dwóch Portugalczyków kłóciło się [...] w okolicy Rosmary lane, a kiedy pewien Anglik, przechodzień, chciał ich pogodzić jeden wyciągnął nóż i dźgnął go w brzuch. Przez kilka minut trzymał się płotu, a kiedy zaczął krwawić wszedł do przyległego domu, usiadł na krześle i zmarł natychmiast".

11 Zginęło 29 Anglików i 49 Angielek, Lodge R. 1933, s. 225; por. Sutherland L.S. 1932, s. 367-387. W dniu 31 marca $1761 \mathrm{r}$. w południe miało miejsce kolejne, pięciominutowe trzęsienie, zob. „Philosophical Transactions (1683-1775)", vol. 52, 1761-1762, s. 141 i n.

12 Trzęsieniu ziemi poświecił cały rozdział, zob. Journey. 1770, t. I, s. 137-150. Na początku 1756 r. w prasie brytyjskiej informowano, że „wielką liczbę cieśli i im podobnych zatrudniono na wyjazd do Lizbony za 4 i 6 funtów na miesiąc, aby wspierać odbudowę miasta”, „London Magazine”, 1756, vol. 25, s. 41-42. Pierwsze relacje o skutkach, o zabitych Anglikach, okolicznościowe przemówienie Jerzego II w Izbie Lordów oraz informacje o pomocy międzynarodowej (hiszpańskiej i brytyjskiej), np. w: „London Magazine”, 1755, vol. 24, s. 585-587, 594. Wytłumaczenie kataklizmu w kategoriach „kary bożej” opublikowano w „London Magazine”, 1756, vol. 25, s. 67 i n., grożąc, że ,zepsuty” Londyn będzie następnym. Problematyka trzęsień ziemi podejmowana była w prasie także przed rokiem 1755 r., zob.: „Gentleman’s Magazine”, 1750, vol. 20, s. 89; także Pereira A.S. 2009, s. 466-499.

13 Amory H. 1971, s. 65-83; Rivero A.J. 1994, s. 520-533; Battestin M.C. 2002, s. 215-233.

14 Baretti krytykował chętnie: „w Podróżach po Hiszpanii pani d’Aulnoy mówi się, że każdego podrzutka (bastard) przyniesionego do ochronki w Madrycie traktuje się, wedle hiszpańskiego prawa jako szlachcica. Stwierdzenie to powtórzyli łatwowierni autorzy Dictionnaire Encyclopedique. Nie jest to prawdą. Bastard jest bastardem tak samo w Madrycie, jak gdzie indziej”, Journey. 1770, t. II, s. 308 ; zob. Ilie P. 1976, s. 375-390; Hester N. 2007, s. 87-102; Le Voyage en Espagne. 1998; Herr E.F. 1974, s. 21-67; Smith A.E. 2003, s. 178-202. 
odrębność od katolicyzmu, który był dla nich barbarzyńską herezją, bliską pogaństwu rodem z wnętrza Afryki. Hiszpanię - jedno z wielkich mocarstw Europy - postrzegano przede wszystkim przez pryzmat stereotypu wiejskiej biedy, nietolerancji, bigoterii, inkwizycyjnych okrucieństw oraz cywilizacyjnego zacofania w porównaniu z Holandią, Anglią i Francją. Giuseppe Baretti nie omieszkał tego zauważyć. Dręczył go smród śmieci na madryckich ulicach, który przypominał mu rzymską Cloaca Maxima. Notował także, że „dostaliśmy obiad złożony z cieciorki doprawionej zjełczałą oliwą i solonej ryby, którą jak sądzę posolono, kiedy już zgniła. Co za zapach! Otrułby konia trojańskiego" 15 . Zauważał nędzę wsi oraz lenistwo mieszkańców, co skłaniało go do zapisania, że „Moriscos byli o wiele bardziej pracowici i przedsiębiorczy niż ich następcy”, czyli hiszpańscy chłopi ${ }^{16}$.

Gdy książka Barettiego pojawiła się na londyńskim rynku w 1770 r., znalazła tam konkurencję w postaci relacji napisanej w latach 1760 i 1761 przez Edwarda Clarke'a, kapelana brytyjskiego ambasadora w Madrycie i opublikowanej w roku $1763^{17}$. Dalsze uwagi dotyczyć będą obu publikacji, ponieważ prezentowały odmienne style opowiadania o podobnych, ale inaczej postrzeganych doświadczeniach podróżniczych. Raport Clarke’a (napisany także w formie listów) traktować będę jako odniesienie, dzięki któremu przedstawić można specyfikę opisu stosowaną przez Barettiego. Iberyjskie trasy obu podróżnych często się nakładały, czasem pisali o tych samych miejscach, lecz robili to w inny sposób.

Pozostając jeszcze przy zdewastowanej przez tsunami Lizbonie - Clarke dotarł do miasta w styczniu 1762 r. i był to ostatni etap jego iberyjskich peregrynacji, z kolei Baretti przypłyną w końcu sierpnia 1760 r. i w stolicy Portugalii rozpoczynał swoją przygodę. Obaj dostrzegli np. urodę miejscowych kobiet (Clarke uważał, że ładniejszych niż Hiszpanki) oraz próbę odbudowy niektórych budynków (np. Arsenału). Clarke twierdził, że w gruzach legło 25\% miasta i tysiące ludzi zginęło w pożarach, natomiast Baretti uważał, że zniszczeniu uległo dwie trzecie Lizbony. Odmienności te mogły jednak wynikać z korzystania z innych informatorów. Clarke pisał ,po reportersku”, na szybko, przed wyjazdem do Anglii, Baretti zaś puścił wodze pisarskiej swadzie i oddał się dywagacjom pokrewnym eseistyce ${ }^{18}$.

Różnice obu relacji wymagają dodatkowego komentarza. Baretti swoje wspomnienia zamierzał początkowo wydać we Włoszech, w postaci listów napisanych po włosku do braci, jako podróżny epistolarny diariusz, pokrewny stylistyce paysage moralise ${ }^{19}$, pisany ze świadomym dystansem do opisywanego przedmiotu. Realizację tego projektu uniemożliwiły jednak wysiłki dyplomatów portugalskich, którzy protestowali przeciwko krytyce i złośliwościom, którymi raczył czytelników. Planowana kariera literacka legła w gruzach i po powrocie do Londynu Baretti przeredagował tekst, rezygnując z wielu uszczypliwości, i dedykował go prezesowi brytyjskiej Akademii Sztuki, instytucji, której właśnie został sekretarzem. We wstępie do angielskiego

15 Journey. 1770, t. II, s. 5. Książkę uznano za ciekawą — fragment nazwany „,medytacje polityczne w Hiszpanii” przedrukował m.in. miesięcznik „Oxford Magazine” (1770, vol. 5, s. 60-61), a fragment o „Zwyczajach w Madrycie” „London Magazine” (1770, vol. 39, s. 504-506) — ale także krytykowano, Journey. 1770, t. II, s. 421, 531. W swojej przybranej ojczyźnie, Wielkiej Brytanii, Baretti jako Włoch także podlegał stereotypizacji, zob. Canepa A.M. 1971, s. 107-146.

${ }^{16}$ Journey. 1770, t. II, s. 127-130, 255; o „czarnej legendzie” Hiszpanii zob. Hontanilla A. 2008, s. 119-143. Na temat programu reform Karola III zob. Kuethe A.J., Andrien K.J. 2014, s. 231 i n. Konstatacja o smrodzie, pierwsza jaką zaznaczył po przyjeździe do Madrytu, nawiązywała do często formułowanej oświeceniowej dyrektywy upiększania miejskiej panoramy w kategoriach uporządkowania (np. chodniki dla pieszych, w Paryżu w 1782 r.), publicznej higieny i oczyszczania miast, zob. Harouel J.-L. 1993.

${ }^{17}$ Letters. 1763. Brat ambasadora, Christopher Hervey, napisał książkę, która ukazała się drukiem w Londynie dopiero w roku 1785, Hervey Ch. 1785.

18 Journey. 1770, t. I, s. 136 i n.; Letters. 1763, s. 351 i n.

19 Wydania: Lettere Familiari. 1967, s. 119 i n.; Baretti G. 1994. Na temat paysage moralisé zob. Neumann B. 2010, s. 9. Kłopoty Barettiego z cenzurą i władzami Wenecji zob. Preto P. 2004, s. 438. 
wydania swojego dzieła sprecyzował cel swojej podróżniczej relacji (traveller's narrative). Był nim „w miarę sprawiedliwy obraz Hiszpanii” stworzony zarówno dzięki opisaniu „wyglądu kraju, jak i manier jego mieszkańców". Do gatunku literatury podróżniczej podchodził z dystansem światowca, twierdząc, że „większość piszących o podróżach [...] przez ponad dwa ostatnie stulecia starała się przykleić łatę każdej nacji, poza swoją"20. Ostatecznie relacja z iberyjskiej podróży, która celowo (także z powodu trwającej wojny) prowadziła nie najkrótszą drogą z Londynu do Genui (przez Portugalię, Hiszpanię i francuskie Midi), spisana została w formule epistolograficznej. Był to niemal obowiązkowy sposób pisania w podróży doby Oświecenia. Można się zastanawiać — jak czynili to z różnych perspektyw Roman Krzywy i Wojciech Tygielski — czy sam dobór formy i retoryki relacji już definiował notowane spostrzeżenia i obserwacje ${ }^{21}$. Czy pisanie listów, komponowanych przynajmniej w teorii hic et nunc, mogło ustrzec podróżnika przed zapisywaniem jakże często powtarzanych banałów? Listy z podróży — zapożyczenie od rozkwitającej właśnie powieści epistolarnej nie wymaga dłuższego uzasadniania - mogły być sposobem na formułowanie własnych, czasem kontrowersyjnych sądów na tematy nie tylko związane z przedmiotem obserwacji, ale też być wyrazem estetycznych i politycznych poglądów ${ }^{22}$.

Włoch, podobnie jak Anglik, nie był zatem oryginalny. Obaj korzystali z modelu dobrze już utrwalonego. Baretti czynił zapiski — tak jak mu radził przed wyjazdem Samuel Johnson — regularnie i rozwlekle, przywiązując dużą wagę do poprawnej stylistyki. Docelowo zamierzał swoją relację wydać drukiem nie jako przewodnik, ale raczej popis swady i erudycji oraz dowód zmysłu „socjologicznie” i historycznie zorientowanej obserwacji. Nie krył się też z zamiarem wpisania swojej peregrynacji w krąg szerszych kulturowych odniesień. „Moją podróż z Lizbony do Meridy, z Meridy do Fraga, a z Fragi do Piera można w pewnej mierze porównać z poetyckim wędrowaniem Dantego przez Piekło, Czyściec i Raj” — konstatował w ostatniej części swojej publikacji ${ }^{23}$. Ambicje literata umiał jednak podporządkować wymogom rynkowego popytu. Redagując angielską wersję dopisał do niej dokładny diariusz swojej kolejnej hiszpańskiej podróży z 1768 r., nazywając ten niemal osobny tekst instrukcją dla osób podróżujących do Madrytu i zaopatrując ją m.in. w słownik użytecznych zwrotów, wykaz najczęściej używanych tras, zwięzłe opisy miejscowości, odległości między nimi i miejsc wartych postoju. Potrafił także w ramach przyjętej konwencji prowadzić swego czytelnika niczym przewodnik, pokazując mu — jak w ogrodach rezydencji w Aranjuez — piękno krajobrazu i najciekawsze zabytki ${ }^{24}$.

Clarke także już we wstępie swojej książki deklarował zamysł stojący za publikacją. Było nim ,zaspokojenie ciekawości przyjaciół, lub przydatność (utility) szerszemu gronu czytelników". Co więcej, duchowny precyzyjnie określał cel podróżowania tout court. Obce kraje odwiedza się po to, aby „przywieść o nich informacje, które skorygują przesądy i błędy na ich temat, ulepszą nasze oceny i przyczynią się do powstania sprawiedliwych opinii na temat innych narodów"25. Chciał skreślić rzetelny obraz Hiszpanii, znając dobrze jej historię przyznawał się do nieznajomości języka, co starał się (raczej nieskutecznie) rekompensować, próbując porozumieć się po łacinie. Lektura listów Clarke’a dowodzi, że był drobiazgowym pedantem akademickiego chowu. Opisywał każde miasto przez które przejeżdżał, a niektóre, takie jak Toledo lub Segowię, dokładnie. Lubował się w zestawieniach i tabelach; wykazowi obrazów w galerii

${ }^{20} \mathrm{~W}$ oryginale: to form an idea tolerably just of Spain by exhibiting as well the face of the country as the manners of the inhabitants, Journey. 1770, t. I, Preface, s. vi-vii; por. the greatest part of travel-writers [...] have for these two centuries past and more, endeavoured to give a bad character to every nation, except their own, Journey. 1770, t. III, s. 291; także Black J. 1990, s. 185-202.

21 Tygielski W. 2014, s. 13-46; Krzywy R. 2013.

${ }^{22}$ Le Grandic E. 1988, s. 1047-1063; Whyman S.E. 2007, s. 577-606; Smith A.E. 1998, s. 77-96.

${ }_{23}$ Journey. 1770, t. IV, s. 54; por. Strawn M. 2012, s. 561-575.

${ }^{24}$ Journey. 1770, t. IV, s. 190-318; opis Aranjuez w: Journey. 1770, t. II, s. 230 i n.

${ }^{25}$ Letters Concerning the Spanish Nation, wstęp. 
w Escurial towarzyszył wykaz wszystkich regimentów hiszpańskiej armii, okrętów wojennych oraz bilans finansów państwa. Obsesyjnie liczył, ważył i mierzył, przepisywał dokumenty, kopiował starożytne inskrypcje, katalogował rękopisy królewskiej biblioteki. Nie ukrywał poczucia wyższości. Opisując stan wiedzy i poziom hiszpańskiej literatury nie omieszkał zaznaczyć, że ograniczają je „,brak wolności prasy” oraz inkwizycyjna cenzura ${ }^{26}$.

Baretti znał książkę Clarke'a i na marginesie swojego dzieła podejmował z nią kilka razy krótkie polemiki, nie szczędząc duchownemu złośliwości, pomawiając o antykatolickie fobie oraz uznając go za człowieka „kostycznego umysłu”27.

Relacja Barettiego skłania do formułowania pytań, które od dawna należą do kanonu badań nad spisanymi podróżniczymi obserwacjami: na co patrzył autor i co zauważał, o czym nie pisał lub czego nie chciał wiedzieć, gdzie pośród setek relacji podróżnych z XVIII w. należy ulokować zapis jego iberyjskiej podróży? Czy sam wybór krajów, które opisywał, miał być próbą odróżnienia się od innych autorów, niezmiennie opisujących dominujący, choć po swojemu opisywany iter italicum? Można śledzić jego uwagi pod kątem wypowiadanych ocen, szukać zapisu troski, współczucia lub pogardy, emocji, które wywoływały hiszpańskie pustkowia, spustoszona przez kataklizm Lizbona, ślady włoskiej kulturowej „,swojskości” w czasie wizyt w galeriach Madrytu lub iberyjskiej „,inności”, zauważanej w opisach corridy ${ }^{28}$, towarzyskiej obyczajowości salonów bądź zabawowych zachowań ulicy. Baretti dostrzegł zaraz po przybyciu, że ,jedną z rzeczy, która najbardziej zaskakuje cudzoziemca, który włóczy się po mieście, jest ogromna liczba Murzynów, mrowiących się na każdym rogu" ${ }^{29}$. Jako mieszkaniec Londynu, stolicy innego kolonialnego mocarstwa, nie był na pewno zaskoczony samym widokiem Afrykanów (choć ich proporcja w Lizbonie była dużo większa). Dał temu zresztą wyraz. Pewnego dnia obserwował z nabrzeża Tagu „dwóch pływających Murzynów, którzy fikali kozły w wodzie. Gdybym nie widział wcześniej czarnoskórych pomyliłbym ich z jakimś gatunkiem ryb [...] za parę reis kazałem im zaśpiewać kilka piosenek w ich mozambickim języku, z którego nic nie zrozumiałem poza tym, że często się rymowały"30.

O różnym sposobie patrzenia przez Barettiego i Clarke’a na iberyjskie odmienności świadczą ich metody zapisywania pamięci ,wizualnej”, odnoszącej się do obserwacji miejsc, ludzi i zjawisk, oraz „kulturowej”, odwołującej się do posiadanej wiedzy oraz do asocjacji, jakie przedmiot obserwacji wywoływał. Francuski ekonomista Etienne de Silhouette, który zwiedził Portugalię, Hiszpanię i Włochy, pisał w przedmowie swojej relacji, że podróżnik powinien być obserwatorem bezstronnym oraz „badać wszystko” (il doit examiner tout): obyczaje, język, klimat, zabytki starożytności oraz dzieła malarstwa ${ }^{31}$. Były to zalecenia trwale umocowane w relacjach podróżniczych, a w XVIII w. niemal obowiązkowe według Johanna Georga Keysslera, autora opasłego Neuste Reise, przewodnika po wielu krajach Europy (wydanie niemieckie z 1741 r., thumaczenia angielskie z 1756 r.). Baretti stosował się do tej dyrektywy, choć nieco po swojemu. Informował swego czytelnika, że ,pokaże mu to co sam widział, usłyszy co on usłyszał, poczuje co czuł, a nawet pomyśli i wyobrazi sobie to, co ja sam myślałem i sobie wyobrażałem”32. Ten ambitny

${ }^{26}$ Letters. 1763, s. 49. O zjawisku odwrotnym, tzn. opisie Anglii przez podróżników hiszpańskich zob.: Bolufer M. 2015, s. 93-112; Bolufer M. 2009, s. 83-102.

${ }^{27}$ Opisując katedrę w Toledo Baretti uznał ją za budowlę gotycką, ,prawie tak dużą jak w Mediolanie”, a w przypisie dodał: „Pan Clarke mówi, że nie jest zbyt wielka, jest jednak większa niż jakakolwiek gotycka katedra w jego kraju”, Journey. 1770, t. I, s. 144; t. II, s. 197, 199 (rigid way of thinking), s. 249.

28 Journey. 1770, t. III, s. 177 i n. W liście z Lizbony z 23 lipca 1763 r., który wydrukował „London Magazine” (vol. 32, 1763, s. 487), napisano: „W powieściach często czytałem o walkach byków i oczekiwałem przedniej rozrywki, ale bardzo się rozczarowałem, bo wedle mnie to nic więcej niż rzeź wielu biednych zwierząt, znacznie bardziej okrutna niż my to robimy".

29 Journey. 1770, t. I, s. 273.

30 Journey. 1770, t. I, s. 169.

31 [de Silhouette M.]. 1770, s. XI-XII, cyt. za: Le Grandic E. 1988, s. 1057.

32 Journey. 1770, t. I, Preface, s. V-VI. 
zamysł można skonfrontować ze sposobem, w jaki dwaj podróżnicy, jak się wydaje różni pod każdym względem (współobserwatorem był tu młody Ignacy Potocki), notowali swoje wrażenia oglądając to samo miejsce, np. nadmorskie San Remo. Obaj przybyli tu morzem: Włoch 17 listopada 1760 r., a Polak 25 czerwca 1770 r. i zabawili tylko jeden dzień. Potocki w diariuszu, a więc zwięźle, zgodnie z regułami takiego opisu, odnotował tylko sady cytrynowe i oglądaną (z morza) genueńską fortecę. Baretti poświęcił miejscowości więcej uwagi. Dostrzegł także obronny bastion, krótko wspomniał o miejskich kościołach, rozwodził się natomiast nad stadami gęsi (oche d'aqua), zachwycał warkoczami i ozdobnym nakryciem głów miejscowych kobiet. Podobnie jak Polak dostrzegał obfitość cytryn i pomarańczy, notując, że 1000 sztuk tych owoców kosztuje dwa genueńskie liwry (i zaraz przeliczył, iż to równowartość 18 pensów). Przypomniał także o szczególnym przywileju mieszkańców, którzy corocznie dostarczali do Rzymu palmy z okazji Niedzieli Palmowej (zarabiając na tym 1000 skudów, też przeliczonych na angielską monetę, bo scudo to 5 szylingów) ${ }^{33}$. Na pierwszy rzut oka porównanie wypada na niekorzyść Potockiego, wynika to jednak z innych konwencji literackich przyjętych przez obu podróżujących, z prywatnej natury diariusza a publicystycznego celu listów. Natomiast zdolność obserwacji obu autorów, a także intelektualne kompetencje, mimo „klasowej” różnicy, można uznać za podobne.

Na przykładzie źródeł pozostawionych przez peregrynantów można również rozważać: kto patrzy (i opisuje), a zatem czego można się spodziewać po jakości relacji wiedząc, przynajmniej w zarysie, jakimi kompetencjami dysponował obserwator. W przypadku Clarke’a i Barettiego udzielenie precyzyjnej odpowiedzi nie jest trudne. Po pierwsze, Baretti był Włochem, podróżnikiem często przemieszczającym się po Europie (mimo w miarę „stałego” adresu w Londynie), Clarke zaś Anglikiem, którego obowiązki na pewien czas zmusiły do pobytu za granicą. Pochodził z dobrze wykształconej rodziny duchownych (ojciec był m.in. kapelanem domowym księcia Newcastle), był absolwentem kolegium św. Jana w Cambridge, protestanckim duchownym, który dzięki możnej protekcji został wiejskim proboszczem, a koneksje umożliwiły mu przebywanie zagranicą w otoczeniu brytyjskich dyplomatów (po powrocie z Hiszpanii w latach 1763-1768 był sekretarzem gubernatora Minorki).

Baretti, o 11 lat starszy, patrzył na oba państwa na Półwyspie Iberyjskim oczyma europejskiego konesera o szerszych niż Clarke horyzontach intelektualnych i większych ambicjach osobistych. Pochodził z Turynu, ale mieszkał w Londynie, należał do europejskiej „republiki piszących", piórem zarabiał na życie, był poliglotą, leksykografem i dziennikarzem, autorem słownika angielsko-włoskiego, żywo angażował się w wielkie spory literackie epoki, broniąc m.in. wartości włoskiej literatury przed krytyką formułowaną przez Woltera.

Zapisy wrażeń i obserwacji z wojaży u obu przybierały inną postać. Obaj podróżnicy poświęcili uwagę hiszpańskim królowym. Baretti wspominał o królowej Barbarze (1711-1758), portugalskiej żonie nieżyjącego już Ferdynanda VI, otyłej astmatyczce obdarzonej wielkim talentem muzycznym. Pisząc o niej wyrażał nie własne, lecz zasłyszane opinie, iż ,znana była tylko ze swej miłości do muzyki i z pobożności. Pierwsza powodowała, że dawała prawie 4000 brytyjskich funtów rocznie sławnemu Farinelli, który przez wiele lat był jej stałym ulubieńcem i któremu zapisała wszystkie muzyczne instrumenty i wielki zbiór muzyki, może największy jaki był na świecie" ${ }^{\text {34 }}$. Baretti wolał opowiadać o sytuacjach niż o twarzach. Często streszczał rozmowy z różnymi osobami, w tym z zakonnikami, oberżystami, spotkanymi paniami z towarzystwa, nie poświęcając jednak interlokutorom nadmiernej uwagi. Np. wspominając o spotkaniu w Badajoz z kardynałem Filippo Acciauoli, nuncjuszem papieskim wygnanym (za sprzyja-

33 Journey. 1770, t. IV, s. 168-173; Potocki I. 2016, s. 138.

34 Journey. 1770, t. II, s. 310-312. Baretti dostrzegał odmienne podejście nowego króla (Karola III): „od czasu jak objął tron nie pozwalał, aby opery włoskie wykonywano w Madrycie i w Aranjuez, jak to miało miejsce za poprzednika. Skończyły się czasy królowej Barbary, kiedy wydawano miliony na włoskich muzyków", Journey. 1770, t. III, s. 131-132. 
nie jezuitom) z Portugalii, wspomina o tematach poruszanych w rozmowie, niewiele nadmieniając o samym kościelnym dostojniku ${ }^{35}$.

Edward Clarke sportretował szwagierkę Barbary, Marię Amelię saską (1724-1760) w sposób bardziej osobisty, a po jej śmierci (27 września, gdy zarówno Clarke, jak i Baretti przebywali w Hiszpanii) napisał, że „była kobietą niezwykle wysoką, miała grube kości i rysy, o raczej męskim wyglądzie bez pretensji do urody, ale brak powabów nadrabiała duchem. Polski temperament był aż nadto widoczny w tej hiszpańskiej królowej”. Ostatnie zdanie ozdobił przypomnieniem, że córka Augusta III potrafiła „palnąć w ucho” (box on the ear) swoje damy dworu ${ }^{36}$. Portrety osobowe, zwłaszcza postaci znanych, przyciągały uwagę czytelników, jeżeli bardziej zbliżały się do zapisu realistycznego, często niepozbawionego zamierzonej złośliwości ${ }^{37}$. Pod tym względem Baretti wydaje się obserwatorem bardziej wydarzeń niż poszczególnych person, raczej konstruktorem fabuł niż kronikarzem drobiazgów. Skupiał się na kontekstach, w których ludzi oglądał i spotykał, a twarze były dla niego mniej istotne. Notował, np. że ,panowie witają się z damami przyklękając szybko i na krótko, tak jak my we Włoszech do naszych najlepszych [sic! best - P.D.] Madonn, kiedy się śpieszymy", natomiast mężczyźni wymieniają powitanie całując się w lewe ramię, oraz że „Hiszpanki i Portugalki uwielbiają chodzić na msze każdego dnia w roku”, dodając ,a Włoszki tylko w niedzielę i święta, zwłaszcza jak są młode”38. Wdał się w dłuższy opis madryckich przyjęć, na które go zapraszano. Zaobserwował, że po kolacji nie ma tam angielskiego zwyczaju „krążącej butelki”, a jedynie filiżanka (dish) kawy i kieliszek maraschino. Wymienił wszystkie dania zimnego bufetu, odnotował, że po jedzeniu jest czas na muzykowanie, tańce lub grę w karty, ale po jedenastej „,goście wymykają się alla Spagnuola jak mówimy we Włoszech tzn. nie informując o tym ani pana ani pani domu"39. Wielokrotnie narzekał na hiszpańskie oberże, ale jedną — w Guadalajara uznał za ,zdecydowanie najlepszą jakie w Hiszpanii widziałem. Prowadzi ją tłusty Francuz, który dał mi na obiad, poza zupą i ragout parę świetnych przepiórek oraz małe ptaszki na rożnie" ${ }^{40}$. Interesowały go „sceny”, które komentował. W kolejnej hiszpańskiej oberży zauważył, że obok ludzi tańczących fandango są też inni, którzy się golą: „W innym kraju byłby to niedopuszczalny brak manier [...] ale tu, nic to nie znaczy”. Obserwację kończyła uogólniająca i wartościująca uwaga: „Ludzie żyją tu naprawdę sans façon, czyli, lepiej mówiąc à la Tartare" ${ }^{\text {41 }}$.

35 Journey. 1770, t. II, s. 66 i n.

${ }^{36}$ Letters. 1763, s. 325-326. Fragment ten przedrukowano w miesięczniku „London Magazine”, 1763, vol. 32 , s. 188 .

${ }^{37}$ Anonimowy angielski podróżnik, którego list z Lizbony z 1763 r. przedrukowała londyńska prasa, rysował portret portugalskiej królowej Marianny Wiktorii (1718-1781), z urodzenia hiszpańskiej infantki i pół Włoszki (Farnese). Królową oglądał na koniu, którego dosiadała po męsku, w wysokich butach z ostrogami, w szkarłatnym płaszczu, kamizelce i długich (też szkarłatnych) szarawarach, z włosami utrefionymi ,jak nasi grenadierzy”. Pisał także, że „panowie mi mówią, iż kiedy poluje, jeśli poczuje naturalną potrzebę, zsiada z konia i załatwia to bez problemu, tak jak mężczyzna w towarzystwie swoich. Żadne damy jej wtedy nie asystują". Drugi raz widział królową już na dworze „w sali koncertowej, gdzie mieliśmy przyjemność słyszeć jak śpiewa razem z dwoma księżniczkami [...] Tutaj królowa wyglądała jak kobieta [...]”. Autor był konserwatywny w swoich poglądach: opisując dworskie zabawy wspominał o kameralnej operze ,gdzie wszyscy wykonawcy byli kapłonami, chociaż niektórzy wyglądali jak kury”, „London Magazine”, 1763, vol. 32, s. 487.

38 Journey. 1770, t. I, s. 161-162; t. II, s. 58. Opis „kobiecej mody w kościele”, Journey. 1770, t. II, s. 302 i n.; por. także Smith T.A. 2006, s. 17 i n.

39 Journey. 1770, t. II, s. 291-299. Zwyczaje te nie były dla niego zaskoczeniem ponieważ w Anglii (i Francji) ,prywatne” koncerty miały już utrwaloną (i znacznie bardziej bogatą niż w Hiszpanii) tradycję, zob. Sadie S. 1958-1959, s. 17-30.

40 Journey. 1770, t. III, s. 193.

${ }^{41}$ Journey. 1770, t. II, s. 58. Użycie zwrotu à la tartare jest dość rzadkie, w XVIII w. pojawia się w kontekstach kulinarnych, w nazwie przepisu na kurczaka i może oznaczać „coś na boku” (w kontekście przepisu na sos do kurczaka), zob. podręcznik edukacji dla kobiet - The Whole Duty of a Woman. 1737, s. 368, oraz zbiór 
Mentalne mapy, o których pisał Böröcz, zależały od stopnia utrwalenia wizerunku, który podróżni przekazywali w swoich relacjach. Baretti dostarcza pod tym względem jednego przewrotnego spostrzeżenia. Obserwując nabożeństwo, w którym brała udział portugalska rodzina królewska, zanotował swoje wrażenia z oglądania jej przejazdu do kościoła. O córkach królowej Marianny Wiktorii napisał, że ,jedna z nich (myślę że trzecia, ale nie jestem pewien) jest niezwykłą pięknością, jeśli wierzyć moim przeklętym oczom [widzącym — P.D.] na 7 czy 8 jardów"42. Chroniczny krótkowidz-okularnik przekazuje potomności spisane doznania, które zapamiętał na podstawie widzianych ulic i pałaców, ludzi, zabytków, książek i obrazów. Czy historyk może i do jakiego stopnia uwierzyć, a raczej — co ważniejsze — w jakiej mierze powinien uwzględniać szczegóły, których informator nie mógł dostrzec albo usłyszeć? Samokrytyczna powyższa uwaga Barettiego każe zastanowić się nie tylko nad wartością przekazów, które dotyczyły chociażby wizyty krótkowidzów w galeriach malarstwa, albo niedosłyszących w operze, ale także — już w szerszym kontekście — nad korelacjami podróżniczej audio- i ikonosfery, by użyć terminów zastosowanych przez Hannę Dziechcińską w badaniach nad kulturą staropolską. Baretti był jednak krótkowidzem spostrzegawczym, który swoją ułomność dyskontował. Przyglądając się kobietom, które z okien oglądały maskaradowe zabawy uliczne, pisał, że „nasze włoskie panie popełniają błąd, kiedy ze złością machają wachlarzami przed twarzą jeśli patrzy się na nie przez lornetkę (a glass), jakby patrzący był bazyliszkiem. To nie moja wina, że jestem krótkowidzem. Nie widzę powodu, aby pozbawiać mnie uroku patrzenia na piękno tylko dlatego, że inni mają dobry wzrok"43. Popisywał się podobnymi refleksjami często: raz jako znawca smaku najlepszych europejskich melonów (w tym przypadku okulary były mu niepotrzebne), innym razem jako czytelnik hiszpańskiej historiografii oraz literatury podróżniczej (m.in. listów pani d'Aulnoy), czy wreszcie jako koneser win, wyznający przy okazji, że to Anglicy przyzwyczaili go do picia, ponieważ „butelka jest u nich główną zachętą do życia towarzyskiego" 44 .

Mamy do czynienia z rozważaniami europejskiego inteligenta o szczególnej intelektualnej proweniencji - dobrze wykształconego Włocha, który w angielskim życiu publicznym odnalazł swoje miejsce. Pewność siebie, zaufanie do erudycji, widać zarówno w kpiących uwagach o listach zakazanych (głównie francuskich) książek, które wywieszano w drzwiach madryckich kościołów, jak w analizie jednej z ,hiszpańskich odrębności”, ludowego zwyczaju ubierania się w capas - obszerne płaszcze i sombreros, kapelusze skrywające twarze - modzie, którą monarchia próbowała ukrócić 45 .

Drugi pokład pamięci dotyczy skojarzeń wywołanych przez powiązanie czynionych na miejscu obserwacji z szerszym, w przypadku Barettiego włoskim kontekstem. Zaprawiony w dziennikarsko-literackich bojach o dobre imię Włochów nie zawsze był komentatorem obiektywnym, a zwykle złośliwym. Robactwo, które gryzło go w portugalskich oberżach, gdzie

przepisów (tłumaczenie z francuskiego) - The Professed Cook. 1769, s. 207. Baretti zwracał uwagę na ludowe zabawy, a taniec, zwłaszcza fandango, przyciągały jego uwagę: „tańca słowami nie można opisać, nie potrafię też przekazać wyobrażenia fandango, mówię tylko, że każda kończyna w takim była ruchu, który — zachowując skromność — można by nazwać uporządkowanymi i harmonijnymi konwulsjami całego ciała”, Journey. 1770 , t. II, s. 30, 48-49.

42 Chodziło o 21-letnią infantkę Marię Franciszkę (1739-1771), zob. Journey. 1770, t. I, s. 157.

43 Journey. 1770, t. II, s. 25. Pod tym względem, tj. uwag krótkowidza, warto porównać relacje Barettiego z jednym z najciekawszych europejskich opisów z podróży z XVIII w., napisanym przez Augusta Moszyńskiego, zob. Dziennik podróży. 1970; por. też Dziechcińska H. 1987, s. 9 i n.

${ }^{44}$ Uwagi o melonach i książce Historiae de rebus Hispaniae (1592) jezuity Juana de Mariana — Journey. 1770, t. II, s. 93; o piciu wina - Journey. 1770, t. II, s. 145; o relacji pani d'Aulnoy, Journey. 1770, t. II, s. 207; zob. Smith A.E. 2003, s. 192.

45 Journey. 1770, t. II, s. 315-318. Na temat oporu kultury ludowej wobec mód europejskich zob. Lamas R. 2006, s. 39-58. 
nocował, porównywał do rzymskich paszkwilantów oraz londyńskich krytyków literackich publikujących swoje opinie w prestiżowych miesięcznikach ${ }^{46}$. Odpierając zarzuty dotyczące zachowania we włoskich teatrach podkreślał, że nie ma tam zwyczaju „syczenia albo rzucania owocami (pelt) w aktorów, w orkiestrę, ani w widzów na parterze, nie ma też barbarzyńskiego zwyczaju drażnienia lub bicia tych, którzy nigdy innych nie drażnią ani nie biją”. Nie było to do końca prawdą i sam zaprzeczając sobie przyznawał, w innej książce swego autorstwa, że w Wenecji ,,jest zwyczaj, obrzydliwy i niesławny, że pluje się z lóż na parter. Wynika to z pogardy jaką dumna szlachta miała i ma dla ludu" ${ }^{\prime 7}$.

Obrońca jakości włoskiej kultury z satysfakcją dostrzegał, że służbę w kaplicy królewskiej Braganzów pełniło „,co niezwykłe, ponad czterdziestu Włochów, śpiewaków i muzyków grających na kilku instrumentach" ${ }^{48}$. Włoskie skojarzenia towarzyszyły mu często, np. niemiłe zapachy hiszpańskich pustkowi przypomniały mu spacery po ogrodzie botanicznym w Chelsea, gdzie towarzyszył goszczącemu w Londynie słynnemu weneckiemu botanikowi Giovanniemu Marsili, „którego często pytałem o tę lub tamtą roślinę, ale zapominałem nazwę tak szybko, jak ją usłyszałem" 49 . W czasie wizyty w klasztorze w Mafra podzielił się swoją opinią na temat wpływu włoskiej kultury na portugalską oraz już bardziej ogólnie skomentował proces jej „plebeizacji”. W klasztornej bibliotece nie mógł znaleźć portugalskiej wersji oper Metastasia, o której słyszał. Zapisał tylko, że „,zapewniano mnie, iż tłumacz przydał metastazjanskim bohaterom służących [dublerów, ang. livery servants — P.D.], którzy opanowują scenę, jak tylko ich chlebodawcy ją opuszczą i prowadzą własne rozmowy (dialogues) z pokojówkami i mamkami bohaterek. Śmiejecie się! Ale jakiż jest błąd w tym, że Achilles ma gońca na posługi, Semiramida - opiekunkę do dzieci (dry nurse), a Deidamia — rozgadaną dziewuchę kuchareczkę, która poleca Murzynkowi, żeby zaniósł pani czekoladę? Jeśli to stanowi o guście portugalskiego dramatu to przekład dzieł Goldoniego w pełni ich uszczęśliwi, tak samo jak oryginał [bawi - P.D.] weneckich gondolierów" ${ }^{50}$. Refleksja ta dotyczy przede wszystkim literackiej i muzycznej pamięci. Baretti, który w Londynie brał udział w polemikach wokół włoskiej opery, w iberyjskim diariuszu nie poświęcił zbyt wiele uwagi muzykom i muzyce. Metastasia uważał jednak za wybitnego pisarza i wiedział, jaką estymą jego krajan cieszył się na Półwyspie Iberyjskim oraz jak wielki wpływ wywarł na tamtejszą produkcję muzyczną. Jego libretta, często pisane na zamówienie dworu, ale także adaptowane na hiszpańskie potrzeby do muzyki wielu kompozytorów, gościły na miejscowych scenach ponad 50 razy w latach $1738-1769^{51}$. Przypuszczalnie dwie opery, do których nawiązywał, nie były mu zupełnie nieznane ${ }^{52}$. Znał zapewne libretto (Matastasia) i operę Semiramide riconosciuta. Temat ten podejmowany był m.in. przez Glucka (w 1748 r.), ale przede wszystkim przez dyrektora lizbońskiej opery (do czasu jej zawalenia się w czasie trzęsienia ziemi), neapolitańczyka, Davide Pereza (premiera odbyła się w Rzymie 1749 r.) oraz przez Niccolo Jommellego (przedstawienie w Madrycie w 1753 r.), kompozytora także obecnego w muzycznym życiu Hiszpanii i Portugalii ${ }^{53}$. Ostatni

46 Journey. 1770, t. II, s. 1.

${ }^{47}$ An Account. 1768, t. I, s. 58; por. Bufalini R. 2010, s. 141-152.

48 Journey. 1770, t. I, s. 160.

49 Journey. 1770, t. II, s. 22; por. [Baretti G.A.]. 1912, s. 190-194.

50 Journey. 1770, t. I, s. 243; por. Rogers P.P. 1941.

51 Stoudemire S.A. 1941, s. 184-191; Leza J.-M.1998, s. 623-631.

52 Nie mógł jednak oglądać premiery Deidamii (z partią Achillesa w dziewczęcym stroju śpiewaną przez kobietę), ostatniej włoskiej opery Haendla, która miała miejsce w Londynie w $1741 \mathrm{r}$. Nie widział też pisanego na tych samych motywach Achille in Sciro, dzieła Jommellego do libretta Metastasia (premiera we Wiedniu w 1749 r.). W latach 1736-1760 metastazjańskie libretto wystawiano 10 razy (z muzyką różnych kompozytorów), zob. Heller W. 1998, s. 562-581; Strohm R. 1997, s. 97-111.

53 McClymonds M.P. 1980, s. 326-355; Wiesend R. 1983, s. 255-275. 
fragment nawiązywał do procesu zastępowania gatunku opera seria przez jej „lżejsze” wcielenia, zmiany — jak się zdaje aprobowanej (choć z ironią) przez Barettiego - w istotny sposób inspirowanej przez twórczość Goldoniego, pisarza, którego szczególnie nie cenił.

Wielebny Clarke uznał zaś, jak wielu innych podróżników, że temat teatru (ale nie opery) powinien znaleźć się w całościowym opisie kultury odwiedzanego kraju i poświęcił mu osobny fragment, koncentrując się na wyliczeniu hiszpańskich pisarzy oraz na autos, przedstawieniach o tematyce religijnej. Przy tej okazji odnotował, że w teatrach jest brudno, i starał się porównać madrycką publiczność z londyńską. O pierwszej napisał, że „parter wyglądał dziwnie i śmiesznie, jak tłuszcza, wielu stało w szlafmycach i płaszczach, oficerowie i żołnierze mieszali się z brudną hołotą. Tę część [teatru - P.D.] która odpowiada naszej galerii za dwa szylingi, wypełniały tylko kobiety, wszystkie tak samo ubrane, w ciemne suknie i białe wełniane zasłony na głowach". Baretti, który miał znacznie większe obycie teatralne i także odwiedził madryckie teatry, wyjaśniał, że nietypowe nakrycia (męskich) głów wynikały ze zwyczaju nie zakładania kapeluszy na widowni. Można zatem sądzić, iż oglądanie sztuk z gołą głową (tj. w perukach) uznawano za nieobyczajne i niestosowne ${ }^{54}$. O hiszpańskich dramaturgach — Lope de Vega, Calderonie i Moreto pisał dużo i ze znawstwem, wtrącając czasem porównania do praktyki pisarstwa angielskiego. Zauważył m.in. „nie znam żadnego hiszpańskiego pięcioaktowego dramatu” i przyznawał, że śmierć królowej (tj. ogłoszona żałoba) „pozbawiła mnie [możliwości — P.D.] oglądania hiszpańskiego dramatu" ${ }^{55}$.

Wędrując po galeriach sztuki hiszpańskich rezydencji monarszych Baretti z satysfakcją dostrzegał wkład włoskich architektów (Juvarra, Sacchetti) oraz płótna namalowane przez swoich rodaków. Duma z włoskich osiągnięć pojawiała się często, w różnych postaciach. „Ciało św. Jakuba spoczywa w galicyjskiej Compostelli”, pisał „i tamtejsze sanktuarium jest drugie w rzymsko-katolickim świecie. Pierwszym, jak wiecie, jest nasze Loretto" ${ }^{56}$. Nie był może Baretti wielkim specjalistą od ekfrazy, ale i na tym polu dorzucał własny komentarz: „opisanie piórem przedmiotów materialnych [...] jest zupełną niemożliwością. Zrobi to tylko ołówek" 57 . Zwiedzając madrycki pałac monarszy zauważył, że największym malarzem Hiszpanii był Niemiec, Anton Mengs (uwagę tę musiał dopisać po podróży, Mengs przybył bowiem do Madrytu w roku $1761^{58}$ ), ale wymieniał wielu włoskich artystów, m.in. Rafaela, Tycjana oraz (często podkreślając ich lokalne pochodzenie) malarza Jacopo Bassano, złotnika i rzeźbiarza Jacopo Trezzo, Lucchetto (tzn. Luca Cambiasi) z Genui, Giovanniego (Moroni) z Bergamo, Federico Zuccaro z Urbino i współczesnego sobie wenecjanina Tiepolo. Dostrzegł także, iż ,wiele obrazów należało do nieszczęsnego [króla — P.D.] Karola I angielskiego i zostało zbrodniczo sprzedanych Hiszpanii przez jego zbuntowanych poddanych" 59 .

Kwestię ,artystycznych łupów” dostrzegł także Clarke. Zastanawiając się nad Godami w Kanie Galilejskiej Veronese (zapewne kopii, oryginał wisiał w Wenecji) stwierdzał, że „obraz ten kupiono z kolekcji Karola I, ale nie wiem gdzie się znajduje”, po czym zanotował, iż „nie jest w tym momencie ważne czy obrazy z Anglii nabył — jak twierdzą Hiszpanie [spaniards z małej litery — P.D.] don Luis Mendez de Haro czy don Alonzo de Cardinas [Cardenas, ambasador

${ }^{54}$ Letters. 1763, s. 103; Journey. 1770, t. IV, s. 245-250.

55 Journey. 1770, t. III, s. 34, 42.

56 Journey. 1770, t. III, s. 257.

57 Journey. 1770, t. II, s. 249.

${ }^{58}$ Redagowanie dziennika podróży musiało zająć nieco czasu, w tekście wydania z 1770 r. występuje (w przypisie) wzmianka o 1765 r., Journey. 1770, t. II, s. 84.

59 Journey. 1770, t. II, s. 272-286 (cyt. ze s. 285); t. III, s. 115 i n.; o malarstwie w kościołach — Journey. 1770, t. II, s. 319. Clarke szczegółowo, ale bez „narodowych podtekstów” omawiał galerie malarstwa w Escurialu, zob. Letters. 1763, s. 150 i n.; por. Sancho J.L. 1997, s. 515-528; Pelzel T. 1976, s. 405-421; Whistler C. 1986, s. 298-203. O „turystycznym” patrzeniu na sztukę, zob.: Verhoeven G. 2012, s. 29-56. 
Hiszpanii w Londynie w połowie XVII w. - P.D.], jak twierdzi lord Clarendon. Pozostaje faktem, że straciliśmy te płótna, a ich sprzedaż za Cromwella była niegodna i paskudna" ${ }^{\circ 0}$.

Sposób zapamiętywania i zapisywania przez pryzmat dumy z tego co „nasze” wydaje się zabiegiem częstym i naturalnym. Wystarczy wspomnieć, że młody wenecki architekt Giannantonio Selva, który podróżował po Anglii latem 1781 r., wyrażał się cierpko o brytyjskiej architekturze, ale z namaszczeniem podkreślał wkład swoich włoskich rodaków w miejscową kulturę (np. Antonio Zucchi, Giovanni Battista Cipriani, Giuseppe Bonomi) ${ }^{61}$.

Powracając do różnicy „formalnej” obu relacji — Baretti jako literat zastosował świadomie formę listu z podróży, ponieważ był przekonany, że taka forma przekazu umożliwi mu zaistnienie na kulturowym Parnasie. Od informacji ważniejsza była swada i stylistyczna perfekcja, a sama podróż stanowiła pretekst do erudycyjnego popisu. Nie oznaczało to jednak, że zaniedbywał warstwę rzeczowej informacji, przydatną innym turystom. Widać to na przykładzie wzmianek o różnicach w cenach oraz o problemie odmiennych walut, którymi trzeba się było w obcych krajach posługiwać. Porównywanie oraz przeliczanie opłat i wydatków należało do alfabetu podróżniczej codzienności. Henry Fielding w swoich listach do brata podkreślał, że Portugalia jest krajem „skandalicznie tanim”, gdzie przepiórki (a lease of partridges) kosztują 14 angielskich pensów, a za pięć młodych „ptaszków” (fowles) trzeba zapłacić pół korony. Pisarz był przynajmniej w teorii człowiekiem zamożnym, chociaż pod koniec życia borykał się z niespłaconymi długami ${ }^{62}$. W listach Barettiego sprawy dotyczące pieniędzy i kosztów nie były pomijane, ale raczej zostały wplecione — i to z rzadka w porównaniu z wyliczeniami Clarke’a - w tok szerszego wywodu ${ }^{63}$.

Pozostaje jeszcze jedno pytanie, istotne z punktu widzenia informacyjnej i poznawczej nośności obu relacji. Współczesny historyk badający narracje podróżnicze doceni pedantyczną, czasem nieco niespójną, a czasem po prostu uciążliwą w lekturze narrację Clarke'a. Wykorzystując jej rzetelność potrafi zarazem ocenić stereotyp, któremu niekiedy ulegał duchowny, $\mathrm{z}$ akceptującym jego wysiłki znużeniem podąży wraz z nim ulicami hiszpańskich miast, policzy dzieła sztuki w Escurialu, pochyli się nad drobiazgowymi przeliczeniami miar, wag i kursu walut, uzna w końcu jego sprawozdanie za źródło przydatne, choć może nie błyskotliwe, ale należące do „brytyjskiego” kanonu Grand Tour, pisarstwa podróżniczego, który dla XVIII wieku miał znaczenie dominujące i modelujące. Z czterema tomami Barettiego kłopot jest poniekąd większy. Europejski erudyta $\mathrm{z}$ ambicjami pozostawił tekst dopracowany literacko, informacyjnie wielopoziomowy i niejednorodny, kształtujący wizerunek podróżnika, dla którego nie tyle obserwowany przedmiot, ile osobista refleksja o nim stanowiła punkt odniesienia.

Czy współcześni docenili ten osobliwy i bardzo osobisty przypadek pisarstwa, przeznaczony dla wielkomiejskiego, londyńskiego czytelnika? Na angielskim osiemnastowiecznym rynku

${ }^{60}$ Letters. 1763, s. 153-154.

${ }^{61}$ De la Ruffiniere du Prey P. 1982, s. 20-34.

${ }^{62}$ Clarke (Letters. 1763, s. 281) podawał stosunkowo najłatwiejszy przelicznik — jeden brytyjski funt równał się 90 reales de vellon (podstawowa obiegowa srebrna moneta). Z kolei Baretti (Journey. 1770, t. III, s. 318 przypis) zanotował, że: „,peso duro warte jest dwadzieścia reales tj. nieco mniej niż pięć brytyjskich szylingów”. W innym miejscu (Journey. 1770, t. IV, s. 289-292) wymienił zaś ceny we „francuskiej kawiarni” w Burgos, podając m.in. że czarka herbaty kosztowała jednego reala, ciastko czekoladowe - 24 maravedi, a talia kart (dostępna u oberżysty) już 4 reale, Journey. 1770, t. IV, s. 289 i n. Ignacy Potocki w czasie europejskich wojaży dokładnie spisywał kursy miejscowych walut w przeliczeniu na polską, zob. Potocki I. 2016, s. 168.

${ }^{63}$ Podróż statkiem kosztowała go 4 gwinee za zaokrętowanie na brytyjskiej jednostce pocztowej (tzw. packet ship) oraz 23000 reali (tj. 5 portugalskich moidores) płatne kapitanowi po przybyciu do Lizbony, Journey. 1770, t. I, s. 91. W czasie pobytu w Portugalii tylko w jednym miejscu (w przypisie) odniósł się do kursu walut: ,jedno crusado [moneta warta 400 reali — P.D.] oznacza nieco mniej niż angielskie pół korony”, Journey. 1770 , t. I, s. 231. Angielska moneta półkorony warta była 2 szylingi i 6 pensów (jedną ósmą funta). W liście do brata z września 1754 r. Henry Fielding informował (i narzekał), że wynajął dom (pod Lizboną) za 9 moidores (złota moneta portugalska, równa 12 cruzados) rocznie, zob. Amory H. 1971, s. 70. 
wydawniczym odnotowywano i relacjonowano każdą nową publikację, nie szczędząc jej wnikliwych, a czasem złośliwych uwag. Jeden z najbardziej miarodajnych miesięczników poświęconych nowym książkom, który formował krytyczny zmysł czytających środowisk tego stulecia, wydawany od roku 1756 ,The Critical Review”, zauważył i ocenił obie analizowane prace. Nie bez znaczenia było zapewne, że jego naczelny, Tobias Smollett, był nie tylko jednym z luminarzy wyspiarskiej literatury, ale także autorem relacji z podróży po Francji i Włoszech z roku 1766 (zmarł w Livorno), której autobiograficzny wymiar nadal intryguje historyków ${ }^{64}$. Najpierw w 1763 r. wziął pod lupę książkę Clarke'a i recenzował ją tak, jak nakazywały zwyczaje literackie epoki, tzn. streszczając zawartość, przywoływał znaczne fragmenty, wypowiadając także swoje oceny. Recenzent nie był publikacją Clarke’a zachwycony. Doceniał co prawda rzetelność informacji, ale zarzucał autorowi powierzchowność, kompilacje z tekstów trzeciorzędnych autorów oraz zbytnie zaufanie w wartość własnej relacji. „Recenzowanie niewielu prac przysporzyło nam więcej bólu" - tak rozpoczynało się omówienie listów Clarke’a, kończyło zaś stwierdzenie, iż chociaż książka jest „nie bez zalet” i byłaby świetną, ,groszową publikacją” („książeczką za trzy szylingi i szóstaka”), ale w obecnej formie przypomina kraj, który opisuje, czyli „rozległe jałowe przestrzenie przemieszane z kilkoma miłymi miejscami”65.

W siedem lat później ten sam miesięcznik pochylił się z uwagą nad książką Barettiego. Tym razem nie oceniano dyletanta, ale członka „republiki piszących”, literata i człowieka o europejskich horyzontach ${ }^{66}$. W recenzji padło jedno ze słów kluczy europejskiej kultury Oświecenia; styl i wywód Barettiego uznano za „filozoficzny”, co plasowało go w środowisku, które moderowało polityczny i społeczny dyskurs elit. Przypomnijmy jednak, że polifonia oświeceniowej kultury mieściła w sobie także żarliwych krytyków „filozofowania”. Jeśli uznać Barettiego za przedstawiciela tej intelektualnej formacji, to przypomnieć można opinię króla Gustawa III na temat filozofów tej epoki: „panowie ci chcą wszystko urządzać, roszczą sobie pretensję do rządzenia światem, a nie panują nawet nad sobą. Mówią o tolerancji, a są mniej tolerancyjni niż całe kolegium kardynalskie. A jednak to ich opinia decyduje o reputacji i przekazuje ją potomnym"67.

Recenzent „The Critical Review” używał tego określenia z zamierzonym dystansem. Uznając relacje o faktach i wydarzeniach za pouczające i ciekawe wskazywał, że ich autor „moralistą jest słabym, a politykiem jeszcze gorszym”68, ale jego obserwacje, opisy i rozważania spełniają podwójną rolę - realizując wielki literacki, filozoficzny i dydaktyczny cel są zarazem dulce et utile ${ }^{69}$. Przy tej okazji dziennikarz sformułował własną wykładnię, czym powinny być relacje z podróży, i jaką ,społecznie użyteczną” funkcję miałyby spełniać. Fragment ten wskazuje, że w XVIII w. zalew literatury podróżniczej, nie tylko dotyczącej peregrynacji europejskich, spowodował potrzebę opracowania „metodologii” czytania i wykorzystywania tych opowieści. Recenzent pisał, że: „dociekliwy, rozsądny i bezstronny podróżnik, który uwagami ze swojej podróży zagranicę podzieli się łaskawie z czytelnikami (the public), przyczyni się do wyplenienia przesądów i jest dobroczyńcą społeczeństwa. Relacja z podróży, której materia jest zwykle ważna i dobrze uporządkowana, to ciekawe i pouczające dzieło literackie, szczęśliwe połączenie tego co utile, $\mathrm{z}$ tym co dulce. Bawi i podoba się, nie będąc romansową fikcją, przynosi wiele informacji moralnych i politycznych nie nudząc skomplikowaną systematyką. Wspiera i ułatwia stosunki państw odległych od siebie, usuwa z umysłów bezmyślne i ponure antypatie wobec manier, zwyczajów, form rządzenia i wyznania, w których nas nie

${ }^{64}$ Smollett T. 1979; zob. także Sena J.F. 1968, s. 353-369.

65 „The Critical Review”, 1765, vol. 15, s. 295-302.

${ }^{66}$ „The Critical Review”, 1770, vol. 30, s. 194-208, 241-256, 335-348.

${ }^{67}$ Cyt. za: Beaurepaire P.-Y. 2007, s. 238.

68 „The Critical Review”, 1770, vol. 30, s. 348

69 „The Critical Review”, 1770, vol. 30, s. 348; zob. też Golden M. 1976, s. 42-43. 
wychowano. Powoduje, że człowiek staje się łagodny i nawiązuje kontakty z innymi (sociable), a my sami uważamy się za braci ludzkości, dzieło Najwyższego, dobrego Stwórcy — prawda ta, po namyśle oczywista, ale w praktyce zaniedbywana"70.

Wedle opinii wyrażonej w „The Critical Review” dzieło Barettiego spełniało wymóg udanego połączenia tego co pożyteczne, z tym co przyjemne. Nie obyło się oczywiście bez drobnych przytyków. Włoch zaspokajał oczekiwania filologa, a jego angielski to „rzadkość u cudzoziemca", także poeta (czyli literat) nie powinien mu nic zarzucić, ale czasem ponosił go temperament i mentorski ton. „Gust Anglików byłby zaspokojony, gdyby [pan Baretti — P.D.] nie starał się zbyt często błyszczeć, ponieważ jego dowcip (wit) nie jest próby najwyższej, nie jest klasyczny, a jego wyczyny [na tym polu — P.D.] polecić można Holendrowi, Niemcowi, a nawet Piemontczykowi"'71.

Współczesna historiografia uznała iberyjską relację Barettiego za jeden z czołowych utworów osiemnastowiecznej literatury podróżniczo-turystycznej ${ }^{72}$. Czy stało się tak dlatego, że relacja Włocha przekraczała formułę diariusza, zmierzając w kierunku eseistyki? Podróżnicza epistolografia tak wszechobecna $\mathrm{w}$ tamtym stuleciu przechodziła kolejne mutacje podporządkowane zmianom estetycznych oraz filozoficznych wartości. Wystarczy wspomnieć Circularschreiben, list z podróży przez południowe Niemcy napisany w 1750 r. przez Friedericha Klopstocka wraz z dwoma towarzyszami wędrówki, przeznaczony do lektury przez krąg przyjaciół. Nie chodzi jednak tylko o formalną nowinkę - zbiorowe autorstwo, ale o świadome redukowanie przez piszących zawartości „turystycznej”, tj. opisów zabytków, miast itp., na rzecz rozważań o naturze i jakości relacji międzyludzkich. Zamiast podziwiać architekturę Norymbergi Klopstock wolał rozglądać się za ładnymi dziewczętami. Dzielił się z czytelnikami tym, co osobiste i subiektywne ${ }^{73}$. Baretti nie szedł aż tak daleko, chociaż recenzenci obwiniali go o nadmierne „mędrkowanie”: „w jednej chwili, w tonie arystotelejskim decyduje o kwestiach kontrowersyjnych, które pobudzały umysły ludzi znacznie bardziej od niego uczonych i przenikliwych"744. Jego listy z podróży wpisują się w tę fazę podróżopisarstwa widoczną już w połowie XVIII w., w której obserwacje faktów i wydarzeń stają się mniej ważne niż często introspektywne refleksje autorów, a uwagi o zwyczajach, napotkanych ludziach i ich zachowaniu przeważają nad itinerariami oraz opisami zabytków ${ }^{75}$.

Adres Autora:

dr hab. Paweł T. Dobrowolski

Collegium Civitas

plac Defilad 1

XII piętro

00-901 Warszawa

pawdob@hotmail.com

ORCID: 0000-0003-1629-2661

70 „The Critical Review”, 1770, vol. 30, s. 195-196.

71 „The Critical Review”, 1770, vol. 30, s. 197.

72 Terminu Letteratura odeporico-turistica użył w odniesieniu do publikacji Barrettiego (Journey. 1770)

Fido F. 1998, s. 161.

${ }^{73}$ Hilliard K.F. 1986, s. 655 i n. Literacką stylizację oraz przemieszanie perspektyw „turysty” z osobistą refleksją dostrzec można $\mathrm{w}$ tak różnych relacjach jak opisy podróźy osiemnastowiecznych Rosjan, pisane w kategoriach ćwiczenia literackiego, lub dziennik palestyńskiego rabina - kwestarza (shaliah) Hayima Azulai, który odwiedzał po roku 1750 europejskie wspólnoty żydowskie, zob. Dickinson S. 2001, s. 1-29; Lehmann M.B. 2007, s. 2-5.

74 „The Critical Review”, 1770, vol. 30, s. 196.

${ }^{75}$ Charles Batten Jr. 1978, s. 84 i n. 


\section{BIBLIOGRAFIA}

\section{Źródła}

Journey. 1770. A Journey from London to Genoa through England, Portugal, Spain and France by Joseph Baretti [...] in four volumes, London, printed for T. Davies in Russel-street, Covent-Garden, and L. Davis, Holborn.

An Account. 1768. An Account of the Manners and Customs of Italy, with Observations on the Mistakes of some Travellers with Regard to that Country, by Joseph Baretti, London, printed for T. Davis in Russell street, Covent Garden, and L. Davis \& Rymers, Holborn.

[Baretti Giuseppe Antonio]. 1912. [Baretti Giuseppe Antonio], La Scelta delle lettere familiari, a cura di Luigi Piccioni, Bari.

Baretti Giuseppe Antonio. 1967. Opere, wyd. F. Fido, Milan.

Boswell James. 1934-1950. The Life of Samuel Johnson, wyd. G.B. Hill (rev. L.F. Powell), 6 vols., Oxford.

[de Silhouette M.]. 1770, Voyage de France, d'Espagne, de Portugal et d'Italie, par M.S., Paris.

Dziennik podróży. 1970. Dziennik podróży do Francji i Włoch Augusta Moszyńskiego, architekta JKM Stanisława Augusta Poniatowskiego, 1784-1786, wybór i przekł. B. Zboińska-Daszyńska, Kraków.

„Gentleman‘s Magazine”. 1750, vol. 20; 1760, vol. 30.

Giuseppe Baretti. 1994. Giuseppe Baretti, Narrazione incompiuta di un viaggio in Inghilterra, Portogallo e Spagna, wyd. M. Catucci, Roma.

Hervey Christopher. 1785. Letters from Portugal, Spain, Italy and Germany, in the Years 1759, 1760 and 1761, 3 vols., London.

Lettere Familiari. 1967. Lettere Familiari A’Suoi Tre Fratelli Filippo, Giovanni e Amadeo, [w:] G.A. Baretti, Opere, wyd. F. Fido, Milan.

Letters. 1763. Letters concerning the Spanish Nation written at Madrid during the years 1760 and 1761 by Rev. Edward Clarke /.../London, printed for T. Becket and P.A. De Hondt, at Tully's Head in the Strand MDCCLXIII.

„London Magazine”, vol. 24, 1755; vol. 25, 1756; vol. 29, 1760; vol. 32, 1763; vol. 39, 1770.

„Oxford Magazine”, vol. 5, 1770.

„Philosophical Transactions (1683-1775)”, vol. 52, 1761-1762.

Potocki Ignacy. 2016. Ignacy Potocki, Dzienniki i listy z podróży po Europie (1765-1771), wstęp i oprac. A. Kucharski, Staropolskie podróżowanie, t. IV, red. B. Rok, F. Wolański, Kraków.

„The Critical Review”, vol. 15, 1765; vol. 30, 1770.

The Professed Cook. 1769. The Professed Cook, or, the Modern Art of Cookery, Pastry and Confectionary Made Plain and Easy,/.../2nd.edn., London, printed for R. Davis in Piccadilly and T. Caslon opposite Stationers-Hall.

The Whole Duty of a Woman. 1737. The Whole Duty of a Woman, or, an Infalliable Guide to the Fair Sex, London, printed for T. Read in Dogwell Court, WhiteFriars, Fleet Street.

Smollett Tobias. 1979. Travels Through France and Italy, wyd. F. Felsenstein, Oxford-New York. „Universal Magazine”, vol. 5, 1749.

\section{Opracowania}

Adams Percy. 1978. Travel Literature of the Seventeenth and Eighteenth Centuries: A Review of Recent Approaches, „Texas Studies in Literature and Language”, vol. 20, no. 3, s. 488-515.

A Dictionary. 1997. A Dictionary of British and Irish Travellers in Italy 1701-1800, wyd. J. Ingamells, London-New Haven.

Amory Hugh. 1971. Fielding's Lisbon Letters, „Huntingdon Library Quarterly”, vol. 35, no. 1, s. $65-83$.

Batten Jr. Charles. 1978. Pleasurable Instruction: Form and Convention in Eighteenth-Century Travel Literature, Berkeley-Los Angeles. 
Battestin Martin C. 1997. The Authorship of Smollett's Don Quixote, „Studies in Bibliography”, vol. 50, s. 295-321.

Battestin Martin C. 2002. Who Edited Fielding's Journal of a Voyage to Lisbon (1755)? The Case for Arthur Murphy and a New Fielding Essay, „Studies in Bibliography”, vol. 55, s. 215-233.

Beaurepaire Pierre-Yves. 2007. Le mythe de l'Europe française au XVIIIe siècle: Diplomatie, culture et sociabilités au temps des Lumieres, Paris.

Black Jeremy. 1985. The British and the Grand Tour, London.

Black Jeremy. 1990. Tourism and Cultural Challenge. Travel Literature and Xenophobia: the Changing Scene in the Eighteenth Century, [in:] All Before Them: English Literature and the Wider World, 1600-1780, red. J. McVeagh, London, s. 185-202.

Black Jeremy. 1992. The British Abroad: The Grand Tour in the Eighteenth Century, Glos-New York.

Bolufer Monica. 2009. Between Two Shores. Travelers as Cultural Mediators: The Journey to Spain in the Eighteen Century, „Acta Historiae”, vol. 17, no. 1-2, s. 83-102.

Bolufer Monica. 2015. Embridar las Pasiones: Civildad y Barbarie en los Relatos de Viajes Espanoles por Gran Bretania (s. XVIII), „Historia Social”, vol. 81, s. 93-112.

Böröcz Jozef. 1992. Travel-Capitalism: The Structure of Europe and the Advent of the Tourist, „Comparative Studies in Society and History”, vol. 34, no. 4, s. 708-741.

Briesemeister Dietrich.1984. La recepcion de la letteratura espanola en Alemania en el siglo XVIII, „Nueva Revista di Filologia Hispanica”, vol. 33, no. 1, s. 285-310.

Bufalini Robert. 2010. The Lapidation of Giuseppe Baretti and the Invective of His Lettere familiari from Portugal and Spain, „Modern Language Notes”, vol. 125, no. 1, s. 141-152.

Chaney Edward. 1998. The Evolution of the Grand Tour: Anglo-Italian Cultural Relations since the Renaissance, London-Portland.

Canepa A.M. 1971. From Degenerate Scoundrel to Noble Savage: The Italian Stereotype in Eighteenth-Century British Travel Literature, [in:] English miscellany: a symposium of history, literature and the arts, British Council, vol. 22, Rome, s. 107-146.

De la Ruffiniere du Prey Pierre. 1982. Giannantonio Selva in England, „Architectural History”, vol. 25 , s. $20-34$.

Dickinson Sara. 2001. The Russian Tour of Europe before Fonvizin: Travel Writing as Literary Endevor in Eighteenth-Century Russia, „The Slavic and East European Journal”, vol. 45, no. 1, s. $1-29$.

Dziechcińska Hanna. 1987. Ogladanie i stuchanie w kulturze dawnej Polski, Warszawa.

Fido Franco. 1998. La Serietá del Gioco. Svaghi letterari e teatrali nel Settecento, Lucca.

Golden Morris. 1976. Reviews of Travel Books: A Context for Mid-Eighteenth Century Literature, „Modern Language Studies”, vol. 6, no. 1, s. 42-43.

Grand Tour. 1996. Grand Tour: The Lure of Italy in the Eighteenth Century, Exhibition catalogue, red. A. Wilson, I. Bignamini, London.

Harouel Jean-Louis. 1993. L'Embelissement des Ville: l'Urbanisme français au XVIIIe siècle, Paris.

Heller Wendy. 1998. Reforming Achilles: gender, opera seria and the Rhetoric of the Enlightened Hero, „Early Music”, vol. 26, no. 4, s. 562-581.

Herr Elene Fernandez. 1974. Les origines d'Espagne romantique. Les recits de voyage, 1755-1823, Paris.

Hester Natalie. 2007. Travel and the Art of Telling the Truth: Marie-Catherine d'Aulnay's Travel to Spain, „Huntingdon Library Quarterly”, vol. 70, no. 1, s. 87-102.

Hilliard K.F. 1986. What the Seer Saw: Klopstock's Journey to Switzerland in 1750, „The Modern Language Review", vol. 81, no. 3, s. 655-665.

Hontanilla Ana. 2008. Images of Barbaric Spain in Eighteenth-Century British Travel Writing, „Studies in Eighteenth-Century Culture", vol. 37, no. 1, s. 119-143. 
Hunt Margaret. 1993. Racism, Imperialism, and Traveler's Gaze in Eighteenth Century England, „Journal of British Studies”, vol. 32, no. 4, s. 333-357.

Ilie Paul. 1976. Exomorphism: Cultural Bias and the French Image of Spain from the War of Succession to the Age of Voltaire, „Eighteenth Century Studies”, vol. 9, no. 3, s. 375-390.

Kuethe Allan J., Andrien Kenneth J. 2014. The Spanish Atlantic World in the Eighteenth Century. War and the Bourbon Reforms, 1713-1796, New York.

Krzywy Roman. 2013. Wędrówki z Mnemozyne. Studia o topice dawnego podróżopistarstwa, Warszawa.

Lamas Rafael. 2006. Zarzuela and the Anti-Musical Prejudice of the Spanish Enlightenment, „Hispanic Review", vol. 74, no. 1, s. 39-58.

Le Grandic Eric. 1988. Les salons en voyage, ou le débat esthétique, politique et moral des voyageurs français en Italie au XVIIIe siècle, „,Revue d'Histoire littéraire de France”, 88e Année, no. 6, s. 1047-1063.

Lehmann Matthias B. 2007, „Levantinos” and Other Jews: Reading H.Y.D. Azulai's Travel Diary, „Jewish Social Studies”, new series, vol. 13, no. 3, s. 1-34.

Le Voyage en Espagne. 1998. Le Voyage en Espagne: Anthologie des Voyageurs Français et Francophones du XVIe au XIXe siècle, red. B. i L. Bennessar, Paris.

Leza Jose-Maximo. 1998. Matastasio on the Spanish Stage: Operatic adaptations in the Public Theatres of Madrid in the 1730s, „Early Music”, vol. 26, no. 4, s. 623-631.

Lodge Richard. 1933, The English Factory at Lisbon: Some Chapters in Its History, „Transactions of the Royal Historical Society", vol. 16, s. 211-247.

Mączak Antoni. 1984. Peregrynacje, Wojaże, Turystyka, Warszawa.

Mączak Antoni. 1998. Odkrywanie Europy. Podróże w czasach Renesansu i Baroku, Gdańsk.

McClymonds Marita P. 1980. The Evolution of Jommelli's Operatic Style, „Journal of the American Musicological Society", vol. 33, no. 2, s. 326-355.

Neumann Birgit. 2010. Grundzüge einer kulturhistorischen Imagologie: Nationale Selbst- und Frembilder in britischer Literatur und anderen Medien des 18. Jahrhunderts, „Kultur/Poetik”, vol. 10, no. 1, s. 1-24.

Pelzel Thomas. 1976. Anton Raphael Mengs and His British Critics, „Studies in Romanticism”, vol. 15 , no. 3, s. 405-421.

Pereira Alvaro S. 2009. The Opportunity of a Disaster: The Economic Impact of the 1755 Lisbon Earthquake, „The Journal of Economic History”, vol. 69, no. 2, s. 466-499.

Preto Paolo. 2004. I servizi segreti di Venezia. Spionaggio e controspionaggio ai tempi della Serenissima, Milano.

Rivero Albert J. 1994. Figurations of Dying: Reading Fielding's The Journal of a Voyage to Lisbon, „Journal of the English and Germanic Philology”, vol. 93, no. 4, s. 520-533.

Rogers Paul Patrick. 1941. Goldoni in Spain, Ohio.

Sadie Stanley. 1958-1959. Concert Life in Eighteenth-Century England, „Proceedings of the Royal Musical Association", 85th session, s. 17-30.

Sancho Jose Luis. 1997. Mengs at the Palaccio Real, Madrid, „, The Burlington Magazine”, vol. 139, no. 1333 , s. 515-528.

Schudt Ludwig. 1959. Italienreisen im 17. und 18. Jahrhundert, Wien.

Sena John F. 1968. Smollett's Persona and the Melancholic Traveler: An Hypothesis, „Eighteenth Century Studies", vol. 1, no. 4, s. 353-369.

Smith Amy Elizabeth. 1998. Travel Narratives and the Familiar Letter Form in the Mid-Eighteenth Century, „Studies in Philology”, vol. 95, no. 1, s. 77-96.

Smith Amy Elizabeth. 2003. Naming the Un-Familiar: Formal Letters and Travel Narratives in Late Seventeenth- and Eighteenth Century Britain, „The Review of English Studies”, new series, vol. 54, no. 214, s. 178-202. 
Smith Theresea Ann. 2006. The Emerging Female Citizens: Gender and Enlightenment in Spain, Berkeley-Los Angeles.

Staves Susan. 1972. Don Quixote in Eighteenth-Century England, „Comparative Literature”, vol. 24, no. 3, s. 193-215.

Stewart William E. 1978. Die Reisebeschreibung und ihre Theorie im Deutschland des 18. Jahrhunderts, Bonn.

Stoudemire Sterling A. 1941. Metastasio in Spain, „Hispanic Review”, vol. 9, no. 1, s. 184-191.

Strawn Morgan. 2012. Pagans, Papists, and Joseph Addison's Use of Classical Quotations in the Remarks on Several Parts of Italy, „Huntingdon Library Quarterly”, vol. 75, no. 4, s. 561-575.

Strohm Reinhard. 1997. Francesco Corselli's drammi per musica for Madrid, [w:] Strohm, Dramme per Musica. Italian Opera Seria of the Eighteenth Century, New Haven, s. 97-111.

Sutherland L. Stuart. 1932. The Accounts of an Eighteenth-Century Merchant: The Portuguese Ventures of William Braund, „The Economic History Review”, vol. 3, no. 3, s. 367-387.

The Fatal Gift of Beauty. 1996. The Fatal Gift of Beauty: The Italies of British Travellers: An Annotated Anthology, red. M. Pfister, Amsterdam-Athens, Ga.

Tygielski Wojciech. 2014. Podróżopisarstwo historyczne, „Barok. Historia-Literatura-Sztuka”, R. XXI (2), nr 42, s. 13-46.

Verhoeven Gerrit. 2012. Mastering the Connoisseur's Eye: Painting, Criticism, and the Canon in Dutch and Flemish Travel Culture, 1600-1750, „Eighteenth Century Studies”, vol. 46, no. 1, s. 29-56.

Welch Barbara A. 1980. Curiosities and Reflections: British Travelers on the Continent in the Eighteenth Century, „Modern Language Studies”, vol. 10, no. 2, s. 10-25.

Whistler Catherine. 1986. G.B. Tiepolo at the Court of Charles III, „The Burlington Magazine”, vol. 128 , no. 996 , s. 298-303.

Whyman Susan E. 2007. Letter Writing and the Rise of the Novel: The Epistolary Literacy of Jane Johnson and Samuel Richardson, „Huntingdon Library Quarterly”, vol. 70, no. 4, s. 577-606.

Wiesend Reinhard. 1983. Metastasios Revisionen eigener Dramen und die Situation der Opernmusic in den 1750er Jahren, „Archiv für Musikwissenschaft”, 40 Jg., no. 4, s. 244-275.

\section{Observation and reflection - \\ two "tourist" accounts from 18th-century Spain}

Travel accounts of Spain in the Age of Enlightenment are rare. The author investigates two nearly simultaneously produced travel accounts from the early 1760s: one by an Italian, Giuseppe Antonio Baretti, who went from Lisbon to Italy, and another by an Englishman, Edward Clarke, who travelled across Spain in the opposite direction. The two travelers differed in their perspectives: they noticed, appreciated and commented on different social situations, political events and personal encounters which occurred during their journeys. They had different culturally-oriented mindsets and stores of memories, which they conveyed in the printed accounts that they published. The Italian expatriate returning home from London emphasized aspects of Iberian culture different from those noticed by the British official (an embassy chaplain) completing his mission. The author tries to establish the reasons of the differences and similarities in their views, asking whether one of them was that the Englishman pursued an established tradition of report-type travel writing while the Italian ventured to combine observation with a personal and subjective commentary. 